\title{
Effects of heavy metals as stress factors on anaerobic digestion processes and biogas production from biomass
}

\author{
A. Mudhoo • S. Kumar
}

Received: 18 February 2012/Revised: 25 September 2012/ Accepted: 21 October 2012/Published online: 29 January 2013

(C) Islamic Azad University (IAU) 2013

\begin{abstract}
Heavy metals affect the biochemical reactions that take place during anaerobic digestion processes of organic matter. In this review, the different effects observed in anaerobic digestion processes and during the production of biomethane and biohydrogen from several substrates contaminated with and/or inheriting heavy metals from the substrates themselves were discussed. It has been found that heavy metals exert important roles in biochemical reactions. Heavy metals like copper, nickel, zinc, cadmium, chromium and lead have been overwhelmingly reported to be inhibitory and under certain conditions toxic in biochemical reactions depending on their concentrations. Heavy metals like iron may also exhibit stimulatory effects, but these effects have been scantily observed. This review also concludes that the severity of heavy metal inhibition depends upon factors like metal concentration in a soluble, ionic form in the solution, type of metal species, and amount and distribution of biomass in the digester or chain of biochemical reactions which constitute the anaerobic digestion process. A majority of studies have demonstrated that the toxic effect of heavy metals like chromium, cadmium and nickel is attributable to a disruption of enzyme function and structure by binding of the metal ions with thiol and other
\end{abstract}

\footnotetext{
A. Mudhoo ( $\square)$

Department of Chemical and Environmental Engineering,

Faculty of Engineering, University of Mauritius, Réduit,

Mauritius

e-mail: ackmezchem@yahoo.co.uk

\section{S. Kumar}

Kolkata Zonal Laboratory, National Environmental Engineering Research Institute (NEERI), Council of Scientific and Industrial Research (CSIR), I-8, Sector "C", East Kolkata, New Township, EM Bypass, Kolkata 700107, India
}

groups on protein molecules or by replacing naturally occurring metals in enzyme prosthetic groups. This review has not found published data on the effects of heavy metals on the hydrolysis stage of anaerobic digestion process chemistry, and hence further studies are required to depict any changes.

Keywords Inhibition - Acidogenesis - Methanogenesis · Biomethane $\cdot$ Biohydrogen

\section{Introduction}

Anaerobic digestion of solid organic waste such as biowaste, sludge, cattle manure, energy crops and other biomasses for bio-energy production is a widely applied technology (Angelidaki et al. 2009; Appels et al. 2011). Mass reduction, biomethane production and improved dewatering properties of the treated sludge or biomass waste are the main features of the process (Ferrer et al. 2008). The anaerobic digestion process is characterized by a series of biochemical transformations brought about by microbial consortia which convert complex macromolecules into low molecular weight compounds (biomethane, carbon dioxide, water and ammonia). Firstly, organic materials of the substrate-like cellulose, hemicellulose and lignin are liquefied by extracellular enzymes. This initial step which depends on the rate of hydrolysis depends on the $\mathrm{pH}$, temperature, composition and concentration of intermediate compounds and initial constituents of the feedstocks. Soluble organic components including the products of hydrolysis are then converted into organic acids, alcohols, hydrogen and carbon dioxide by acidogens during the acidogenesis phase. The products of acidogenesis are then converted into acetic acid, hydrogen and 
carbon dioxide (Fantozzi and Buratti 2009). Biomethane is produced by methanogenic bacteria from acetic acid, hydrogen and carbon dioxide and from other substrates of which formic acid and methanol are the most important during the third step (methanogenic stage) (Chynoweth et al. 2001; Weiland 2010; Demirel and Scherer 2011).

To the purpose of a balanced and comprehensive review on the different effects that have been observed in stages of the anaerobic digestion processes and biohydrogen production from biomass contaminated with and/or inheriting heavy metals from the parent substrates, a variety of published data are discussed here. This discussion cannot be complete and the authors hope to provoke further research and discussion in professional magazines and scientific journals. It ultimately expands, modifies and enriches the body of knowledge on the effects of heavy metal ions on anaerobic processes.

\section{Process considerations in anaerobic biotechnology}

Anaerobic processes are defined as biological processes in which organic matter is metabolized in an environment free of dissolved oxygen or its precursors (Appels et al. 2011). Anaerobic process may be classified as either anaerobic fermentation or anaerobic respiration depending on the type of electron acceptors (Khanal 2008). In an anaerobic fermentation process, organic matter is catabolized in the absence of an external electron acceptor by strict or facultative anaerobes through internally balanced oxidationreduction reactions under dark conditions (Chandra and Venkata Mohan 2011). Anaerobic respiration on the other hand requires external electron acceptors (Lovley and Nevin 2011) for the disposal of electrons released during the degradation of organic matter. The electron acceptors in this case could be $\mathrm{CO}_{2}, \mathrm{SO}_{4}{ }^{2-}, \mathrm{NO}_{3}{ }^{-}, \mathrm{Fe}$ and $\mathrm{Mo}$.

From both the waste treatment and resource recovery perspectives, it is important to examine some of the important factors that govern the anaerobic bioconversion process. These include organic loading rate, biomass yield, substrate utilization rate, hydraulic retention time (HRT) and solids retention time (SRT), start-up time, microbiology, environmental factors, and reactor configuration (Khanal 2008; Kim et al. 2006; Demirel and Yenigun 2004; Fang and Yu 2000; Sanchez et al. 2000; El-Mashad et al. 2004; Bouallagui et al. 2004; Sanchez et al. 2005; Torkian et al. 2003; Raposo et al. 2006). Anaerobic processes are characterized by high volumetric organic loading rates (VOLRs) and high-rate anaerobic reactors such as the upflow anaerobic sludge blanket (UASB), anaerobic filter, and fluidized bed reactors are capable of treating wastewater at VOLR of 10-45 $\mathrm{kg} \mathrm{COD} \mathrm{m}^{-3} \mathrm{day}^{-1}$, and may at times exceed $120 \mathrm{~kg} \mathrm{COD} \mathrm{m}^{-3}$ day $^{-1}$ in fluidized bed reactors. In principle, a high VOLR indicates that more wastewater can be treated per unit of reactor volume. Biomass yield is a quantitative measure of cell growth in a system for a given substrate, and the biomass yield per mole of ATP totals $10.5 \mathrm{~g}$ volatile suspended solids (VSS) for both aerobic and anaerobic processes (Khanal 2008). However, when considering the metabolic processes of microorganisms, the total aerobic ATP generation is $38 \mathrm{~mol}$, while the anaerobic ATP generation is only $4 \mathrm{~mol}$ ATP $\mathrm{mol}^{-1}$ glucose (Khanal 2008). These result in a significantly lower biomass yield for the anaerobic treatment process compared to the aerobic process. HRT and SRT are two important design parameters in biological treatment processes with the HRT indicating the time the waste remains in the reactor in contact with the biomass. The time required to achieve a given degree of treatment depends on the rate of microbial metabolism. Waste containing simple compounds such as sugar is readily degradable, requiring low HRT, whereas complex wastes, for example, chlorinated organic compounds, are slowly degradable and need longer HRT for their metabolism. SRT, on the other hand, controls the microbial mass in the reactor to achieve a given degree of waste stabilization (Khanal 2008). Thus, high retention times for complex wastes are due to the rate limiting hydrolysis step.

\section{Stress indicators in anaerobic processes}

The microbiology of the anaerobic treatment system is much more complicated than that of the aerobic one. An anaerobic process is a multistep process in which a diverse group of microorganisms degrades the organic matter in a sequential order resulting in a synergistic action. The stability of an anaerobic treatment system is often debated, mainly due to the fragile nature of microorganisms especially methanogens (Yin et al. 2011) to the changes in environmental conditions such as $\mathrm{pH}$, temperature, oxidation/reduction potential (ORP), nutrients and trace/heavy metals availability and/or contamination, and toxicity. When an anaerobic treatment system fails because of lack of proper environmental factors or biomass washout from the reactor, it may take several months for the system to return to a normal operating condition. This lengthy recovery to normal functioning is due to extremely slow growth rate of methanogens (Khanal 2008).

In anaerobic digestion, the acid-forming and the biomethane-forming microorganisms differ widely in terms of physiology, nutritional needs, growth kinetics, and sensitivity to environmental conditions (Chen et al. 2008a, b). Failure to maintain the balance between these two groups of microorganisms is the primary cause of reactor instability (Demirel and Yenigün 2002; Massé et al. 2011). 
Table 1 Past studies on volatile solids destruction (VSD) and volatile fatty acids (VFA) in anaerobic digestion processes

\begin{tabular}{|c|c|c|c|}
\hline Feedstocks & Operating conditions & VSD/VFA & References \\
\hline Vegetable wastes & $\begin{array}{l}\text { Temperature: } 35^{\circ} \mathrm{C} \text { (mesophilic) OLR: } 2.25 \\
\text { g/L day HRT: } 30 \text { days }\end{array}$ & VSD: $68.6 \%$ & $\begin{array}{l}\text { Velmurugan } \\
\text { and } \\
\text { Ramanujam } \\
(2011)\end{array}$ \\
\hline $\begin{array}{l}\text { Acetic acid, } \\
\text { propionic, acid, } \\
\text { butyric acid, } \\
\text { ethanol }\end{array}$ & $\begin{array}{l}\text { Maximum concentrations used: ethanol } \\
(2,400 \mathrm{mg} / \mathrm{L}) \text { acetic acid }(2,400 \mathrm{mg} / \mathrm{L}) \\
\text { propionic acid }(900 \mathrm{mg} / \mathrm{L}) \text { butyric acid } \\
(1,800 \mathrm{mg} / \mathrm{L})\end{array}$ & $\begin{array}{l}\text { Maximum methane yield: } 1,620 \mathrm{~mL} \text { at the following } \\
\text { concentrations: ethanol }(1,600 \mathrm{mg} / \mathrm{L}) \text {, acetic acid } \\
(1,600 \mathrm{mg} / \mathrm{L}) \text {, propionic acid }(300 \mathrm{mg} / \mathrm{L}) \text { and } \\
\text { butyric acid }(1,800 \mathrm{mg} / \mathrm{L}) \text { Inhibition started at } \\
900 \mathrm{mg} / \mathrm{L} \text { propionic acid }\end{array}$ & $\begin{array}{l}\text { (Wang et al. } \\
2009 a, b)\end{array}$ \\
\hline $\begin{array}{l}\text { Cellulose and } \\
\text { glucose }\end{array}$ & Temperature: $35^{\circ} \mathrm{C}$ (mesophilic) & $\begin{array}{l}\text { Inhibition of cellulosic activity at } \\
\text { concentrations } \geq 2 \mathrm{gL}^{-1} \text { Inhibition of glucose } \\
\text { fermentation at concentrations }>4 \mathrm{gL}^{-1}\end{array}$ & $\begin{array}{l}\text { Siegert and } \\
\text { Banks } \\
(2005)\end{array}$ \\
\hline $\begin{array}{l}\text { Organic fraction } \\
\text { of municipal } \\
\text { solid wastes }\end{array}$ & $\begin{array}{l}\text { Temperature } 55^{\circ} \mathrm{C} \text { (thermophilic) HRT } \\
14-18 \text { days OLR } 3.3-4.0 \mathrm{gVS} / \mathrm{L} / \text { day }\end{array}$ & VSD: $69-74 \%$ & $\begin{array}{l}\text { Hartmann and } \\
\text { Ahring } \\
(2005)\end{array}$ \\
\hline Solid potato waste & Temperature: $37{ }^{\circ} \mathrm{C}$ (mesophilic) HRT: $300 \mathrm{~h}$ & $\begin{array}{l}\text { VFA concentrations (mg/g total VFA): acetic acid: } \\
420 \text { butyric acid: } 310 \text { propionic acid: } 140 \text { caproic } \\
\text { acid: } 90\end{array}$ & $\begin{array}{l}\text { Parawira et al. } \\
\text { (2004) }\end{array}$ \\
\hline Sewage sludge & Mesophilic and thermophilic conditions & $\begin{array}{l}\text { Single-stage mesophilic: VSD of } 43.5 \% \text { Single-stage } \\
\text { thermophilic: VSD of } 46.8 \% \text { Co-phase: VSD of } \\
50.7-58.8 \%\end{array}$ & $\begin{array}{l}\text { Song et al. } \\
\text { (2004) }\end{array}$ \\
\hline Cow manure & Temperature: thermophilic conditions & $\begin{array}{l}\text { Addition of VFA affected } \mathrm{CH}_{4} \text { yield, } \mathrm{pH} \text {, and gas } \\
\text { production }\end{array}$ & $\begin{array}{l}\text { Pind et al. } \\
\text { (2003) }\end{array}$ \\
\hline
\end{tabular}

Inhibitory substances are often found to be the leading cause of anaerobic reactor upset and failure. Such inhibitory species are normally present in substantial concentrations in wastewaters and sludges (Chen et al. 2008a, b).

Several parameters have been suggested as stress indicators of the anaerobic digestion process. Some of the most commonly used indicators include measurements of biogas or hydrogen production, gas composition, $\mathrm{pH}$ (Liew et al. 2011), volatile solids destruction (VSD) and volatile fatty acids (VFA) concentrations (Table 1). In general, most of these indicators are suitable for detecting gradual changes, but $\mathrm{pH}$, VS reduction and biogas composition are often too slow for the optimal detection of sudden changes (Angelidaki and Ahring 1994). $\mathrm{pH}$ changes are small in highly buffered systems, as often seen in reactors with high ammonia loads, even when the process is severely stressed (Angelidaki and Ahring 1994). The important feature of a good process indicator is its ability to detect imbalance at an early stage probably because of toxicity from organic (chlorinated compounds, pharmaceuticals, dyes and other persistent organic pollutants) and inorganic (excessive nitrogen and phosphorus, sulphates, oxalates and metallic ions) contaminants. It is also important that the relative change of the parameter following a perturbation is significant compared to background fluctuations and analysis uncertainties. As a matter of fact, the accumulation of both forms of $n$-butyric acid $(\mathrm{HBu})$ has also been used as an indicator of anaerobic digester failure (Lins et al. 2012). However, the experimental results from Lin et al. (1998) indicated that the normal- and iso- $\mathrm{HBu}$-degradation activities of methanogens increased by 14-25\% and 17-43\%, respectively, for each gram of the biomass spiked with 0.02-3.89 mg of $\mathrm{Mn}, \mathrm{Zn}, \mathrm{Ni}, \mathrm{Fe}$ and $\mathrm{Cu}$. These results implied that in the presence of these heavy metals, extreme care should be taken in using $\mathrm{HBu}$ accumulation as an indicator of digester failure.

\section{Effects of heavy metals on anaerobic processes}

The term heavy metals refers to metals and metalloids having densities greater than $5 \mathrm{~g} \mathrm{~cm}^{-3}$ and is usually associated with pollution and toxicity although some of these elements (essential metals) are required by microorganisms at low concentrations. Heavy metals toxicity and the danger of their bioaccumulation in the food chain represent one of the major environmental and health problems of our modern society. Primary sources of pollution are from the burning of fossil fuels, mining and melting of metallic ferrous ores, municipal wastes, fertilizers, pesticides, and sewage sludge (Peng et al. 2006). The most common heavy metals contaminants are: cadmium $(\mathrm{Cd})$, chromium $(\mathrm{Cr})$, copper $(\mathrm{Cu})$, iron $(\mathrm{Fe})$, lead $(\mathrm{Pb})$, nickel $(\mathrm{Ni})$ and zinc $(\mathrm{Zn})$. Heavy metal contamination can 
be a consequence of industrial activities that eliminate residues in the soil and aqueous media that in long term promote their accumulation (Glick 2003) with a majority of the sources being anthropogenic (Zhang et al. 2005). For $\mathrm{Cd}, \mathrm{Pb}, \mathrm{Cu}$ and $\mathrm{Zn}$, their toxicity increases as follows: $\mathrm{Pb}<\mathrm{Zn}<\mathrm{Cu}<\mathrm{Cd}$ (Bååth 1989), depending on numerous abiotic and biotic factors.

Heavy metals and biochemical reactions

Heavy metals also exert some important roles in biochemical reactions (such as the aerobic and anaerobic digestion processes of biomass) being essential to the growth and development of microorganisms, plant and animals. Heavy metals can be stimulatory, inhibitory, or even toxic in biochemical reactions depending on their concentrations (Oleszkiewicz and Sharma 1990; Giotta et al. 2006; Şengör et al. 2009). Different methods have been developed to quantify metal ion toxicity on activated sludge systems. These methods include the inhibition of enzymatic activities, respiratory activities of the bacteria, kinetics of bacterial activities and dynamics of microbial community evolution. A trace level of many heavy metals is required for the activation and/or functioning of many enzymes and co-enzymes during anaerobic digestion (Mata-Alvarez et al. 2000; Bayer et al. 2007; Cirne et al. 2007). This is mostly due to the chemical binding of heavy metals to the enzymes and microorganisms (Brady and Duncan 1994), resulting in the disruption of enzyme structure and activities ( $\mathrm{Li}$ and Fang 2007; Wani et al. 2012). In relatively high concentrations, they can form unspecific compounds, creating cytotoxic effects (Kavamura and Esposito 2010) and altering the optimum biochemistry and performance of the processes. Besides, heavy metals have some differences in relation to their biological importance. For example, iron, manganese and molybdenum are important trace elements and present low, but not negligible, toxicity. On the other hand, antimony, arsenic, cadmium, lead, mercury, silver and uranium are highly toxic with limited biological function (Kavamura and Esposito 2010).

Heavy metals and toxicity effects to anaerobic processes

The effects of heavy metals on the anaerobic digestion process have been widely studied over several decades (Lo et al. 2012; Bertin et al. 2012; Fang 1997; Fang and Chan 1997; Fang and Hui 1994). Most of these studies tended to examine the effect on the overall performance rather than on the individual stages, i.e., acidogenesis and methanogenesis. Results have shown that the severity of metal inhibition depends upon factors like metal concentration in a soluble, ionic form in the solution, type of metal species, and amount and distribution of biomass in the digester. Yue et al. (2007) investigated the anaerobic digestion of cattail by rumen cultures in the presence of $\mathrm{Cu}^{2+}, \mathrm{Cd}^{2+}$ or $\mathrm{Cr}^{6+}$ and the comparative experimental results suggested that the order of toxicity degree of the tested metals on the rumen cultures was $\mathrm{Cd}^{2+}>\mathrm{Cu}^{2+}>\mathrm{Cr}^{6+}$.

The toxic effect of heavy metals is attributed to disruption of enzyme function and structure by binding of the metals with thiol and other groups on protein molecules or by replacing naturally occurring metals in enzyme prosthetic groups (Chen et al. 2008a, b). Many heavy metals are part of the essential enzymes that drive numerous anaerobic reactions. Analysis of ten methanogenic strains showed the following order of heavy metal composition in the cell: $\mathrm{Fe}>\mathrm{Zn} \mathrm{P} \mathrm{Ni}>\mathrm{Co}=\mathrm{Mo}>\mathrm{Cu}$. Whether heavy metals would be stimulatory or inhibitory to anaerobic microorganisms is determined by the total metal concentration, chemical forms of the metals, and process-related factors such as $\mathrm{pH}$ and redox potential (Zayed and Winter 2000). It is generally believed that acidogens are more resistant to heavy metal toxicity than methanogens.

Because of the complexity of the anaerobic system, heavy metals may be involved in many physico-chemical processes including (1) precipitation as sulphide (except $\mathrm{Cr}$ ), carbonate and hydroxides, (2) sorption to the solid fraction, either biomass or inert particulate matter, and (3) formation of complexes in solution with intermediates and product compounds produced during digestion. In addition to physico-chemical form, differences in substrate, bacteria genre, and environmental factors also explain the wide variation (from several to several hundreds of $\mathrm{mg}$ $\mathrm{L}^{-1}$ ) in both the reported dosages of heavy metals and their relative toxicity (Zayed and Winter 2000).

Industrial wastewaters or sludges generally contain many kinds of heavy metals which cause synergistic or antagonistic effects on anaerobic digestion. The level of inhibition is determined by the species and the ratio of the individual components. Although toxicity of most mixed heavy metals such as $\mathrm{Cr}-\mathrm{Cd}, \mathrm{Cr}-\mathrm{Pb}, \mathrm{Cr}-\mathrm{Cd}-\mathrm{Pb}$, and $\mathrm{Zn}-\mathrm{Cu}-\mathrm{Ni}$ was synergistic (Lin 1992), some of the metal mixtures showed antagonistic inhibition. Gonzalez-Silva et al. (2009) have investigated the inhibition effect of iron, cadmium and sulphide on the substrate utilization rate of sulphatereducing granular sludge in a series of batch experiments in a UASB reactor with $\mathrm{Fe}^{2+}$ at $4.0-8.5 \mathrm{mmol} \mathrm{L}^{-1}, \mathrm{Cd}^{2+}$ at 0.53-3.0 mmol L $\mathrm{m}^{-1}$ and sulphide at $4.2-10.6 \mathrm{mmol} \mathrm{L}^{-1}$. It was found that up to a concentration of $8.1 \mathrm{mmol} \mathrm{L}^{-1}$, iron had a positive effect on the substrate utilization rate which increased $40 \%$ compared to the rate obtained without metal addition ( $\left.0.25 \mathrm{~g} \mathrm{COD} \mathrm{g}^{-1} \mathrm{VSS} \mathrm{day}^{-1}\right)$. However, iron concentration of $8.5 \mathrm{mmol} \mathrm{L}^{-1}$ inhibited the specific substrate utilization rate by $57 \%$ compared to the substrate 
utilization rate obtained in the batch amended with $4.0 \mathrm{mmol} / \mathrm{L} \mathrm{Fe}^{2+}\left(0.44 \mathrm{~g} \mathrm{COD} \mathrm{g}^{-1} \mathrm{VSS} \mathrm{Cay}^{-1}\right)$. GonzalezSilva et al. (2009) noted that cadmium had a negative effect on the specific substrate utilization rate at the concentrations tested and cadmium precipitation with sulphide did not decrease the inhibition of cadmium on sulphate reduction. Colussi et al. (2009) have recently evaluated the effectiveness of operating a pilot scale EGSB reactor fed with a solution of ethanol and sodium acetate in the presence of heavy metals. The anaerobic sludge was taken from a brewery wastewater treating UASB reactor. The effects of $\mathrm{Cu}^{2+}, \mathrm{Ni}^{2+}$ and $\mathrm{Cr}^{3+}$ ions on the biomass anaerobic activity were monitored and measured by biomethane production rate and COD removal parameters. Colussi et al. (2009) emphasized a higher biomass sensitivity for copper as compared to nickel and chromium ions. Moreover, copper inhibition was found to be less significant when a metal-free solution was fed to the system before copper ion addition.

The hydrolysis stage

Hydrolysis is the rate-limiting step of anaerobic digestion of semi-solid wastes. In this step both solubilization of particulate matter and biological decomposition of organic polymers to monomers or dimers take place. Thermal, chemical, biological and mechanical processes, as well as combinations of these, have been studied as possible pretreatments to accelerate sludge or biomass hydrolysis (Ferrer et al. 2008) since these pre-treatments cause the lysis or disintegration of sludge cells permitting the release of intracellular matter that becomes more accessible to anaerobic microorganisms. On the other hand, in anaerobic digestion, acidogenic and methanogenic microorganisms have different optimal growth conditions with different physiologies, growth kinetics, nutrient requirements, and sensitivity levels to environmental changes (Jeong et al. 2010). The imbalance between acidogens and methanogens results in digestion failure (Demirel and Yenigün 2002) due to the accumulation of VFA, associated with a drop in $\mathrm{pH}$. Our review has not found published data on the effects of metals on the chemistry of this stage. Hence further investigation is required to depict these probable changes, if any at all.

\section{Effects on acetogenesis stage}

Many factors, including substrate concentration, hydraulic retention time (HRT), temperature, $\mathrm{pH}$, and process configuration, affect the performance of the acidogenesis phase (Veeken et al. 2000; Jeong et al. 2010). In conventional complete mixed digesters, HRT approaches the solid retention time (SRT). Therefore, in order to prevent the washout of microorganisms and untreated organic particles, acidogenesis requires sufficient time for biodegradation by HRT adjustment (Liu et al. 2006). Additionally, a substrate concentration that involves a half velocity concentration $\left(K_{\mathrm{s}}\right)$ in a Monod kinetics is the most important factor. This is because anaerobic processes are severely limited by the enzymatic, microbial activity and production rates. The latter factors in turn are particularly susceptible to the presence and interaction with heavy metal ions (Kavamura and Esposito 2010).

Lin (1992) studied the effects of chromium, cadmium, lead, copper, zinc and nickel on VFA degradation in anaerobic digestion by using serum bottle assays with acetic acid acclimated seed sludge (AASS) and mixed acids acclimated seed sludge (MASS). The main results showed that the relative toxicity of heavy metals to degradation of acetic acid (HAc), propionic acid (HPr), and $n$-HBu was $\mathrm{Cd}>\mathrm{Cu}>\mathrm{Cr}>\mathrm{Zn}>\mathrm{Pb}>\mathrm{Ni} . \quad \mathrm{Cd}>\mathrm{Cu} \geq \mathrm{Zn}=\mathrm{Cr}>$ $\mathrm{Pb}>\mathrm{Ni}$, and $\mathrm{Cd}>\mathrm{Cu}>\mathrm{Cr}>\mathrm{Zn}>\mathrm{Pb}>\mathrm{Ni}$, respectively. In addition, $\mathrm{Lin}$ (1992) found that $\mathrm{Cd}$ and $\mathrm{Cu}$ were the most and $\mathrm{Pb}$ and $\mathrm{Ni}$ were the least toxic heavy metals to VFA-degrading organisms. To some of the heavy metals studied here, VFA-degrading acetogens were more sensitive than HAc-utilizing methanogens and the sensitivity of the VFA degradation to the metallic inhibition was $\mathrm{HPr}>\mathrm{HAc}=\mathrm{HBu}$ for $\mathrm{Cr}, \mathrm{HAc}>\mathrm{HPr}=\mathrm{HBu}$ for $\mathrm{Cd}$ and $\mathrm{Pb}, \mathrm{HPr}>\mathrm{HAc}>\mathrm{HBu}$ for $\mathrm{Zn}, \mathrm{HAc}=\mathrm{HPc}=\mathrm{HBu}$ for $\mathrm{Cu}$, and $\mathrm{HAc}>\mathrm{HPR}>\mathrm{HBu}$ for Ni. Lin (1992) explained these observations on the basis of the mixtures of the heavy metals causing a synergistic inhibition on HAc degradation resulting in inhibition patterns for MASS of $\mathrm{Pb}$ and $\mathrm{Zn}$ dosages being kinetically uncompetitive and competitive, respectively. Later, Yu and Fang (2001) studied the effects of $\mathrm{Cr}^{3+}$ and cadmium on the anaerobic acidogenesis of a simulated dairy waste using serum vials. At cadmium dosages less than $20 \mathrm{mg} \mathrm{L}^{-1}$, the acidogenesis process was found to have been enhanced by the dosage, resulting in a higher degree of acidification, protein conversion, and hydrogen production than the control. At dosages over $20 \mathrm{mg} \mathrm{L}^{-1}$, however, $\mathrm{Cd}$ inhibited the acidogenesis. The $\mathrm{Cr}^{3+}$ at $5 \mathrm{mg} \mathrm{L}^{-1}$ reduced the overall VFA and alcohol generation, degree of acidification, conversions of lactose, lipid and protein, and total biogas production, with the exception of accumulation of hydrogen and propionate. At dosages more than $5 \mathrm{mg} \mathrm{L}^{-1}, \mathrm{Cr}^{3+}$ had a severe inhibition on the acidogenesis. This study also revealed that the $\mathrm{Cd}$ concentrations which caused a $50 \%$ reduction in total VFA and alcohol production, the degree of acidification and cumulative gas production were higher than the corresponding values caused by $\mathrm{Cr}^{3+}$, suggesting that $\mathrm{Cr}^{3+}$ was more toxic to acidogenic bacteria than $\mathrm{Cd}$. 
Effects on methanogenic stage

The biomethane formation step is where the major waste or biomass stabilization occurs. Though the biomethane formed is a high energy compound, its potential recovery and use makes it possible to show waste stabilization efficiency for the anaerobic process. Hence, a change in the predominance of the acid-forming bacteria present in a particular digester (because of a change in substrate) may cause an upset in the system. Such a disbalance may be detected through the production of new first-stage end products which in turn require a group of biomethane organisms that are not present in sufficient numbers for a balanced condition to exist. Fang and Hui (1994) found that heavy metals inhibited the methanogenic activity of anaerobic starch-degrading granules in the order $\mathrm{Zn}>\mathrm{Ni}>\mathrm{Cu}>\mathrm{Cr}>\mathrm{Cd}$, and that granular sludge had higher toxicity-resistance than flocculent sludge, due to the layered structure. Much earlier, Jackson-Moss et al. (1989) found that a calcium concentration of up to $7,000 \mathrm{mg} \mathrm{L}^{-1}$ had no inhibitory effect on the anaerobic digestion of a synthetic waste when the ability of methanogenic bacteria to adapt to high concentrations of calcium was investigated using a 9 L UASB. On the other hand, Codina et al. (1998) found slightly different results when evaluating the specific toxicity of heavy metal toxicity to the anaerobic digestion process. The relative toxicity of metals, obtained by using the inhibition of methanogenic activity assay, was $\mathrm{Zn}>\mathrm{Cr}>\mathrm{Cu}>\mathrm{Cd}>\mathrm{Ni}>\mathrm{Pb}$.

\section{Inhibitory effects}

Many researchers believe that methanogenic bacteria are the most sensitive to toxic material in the waste being treated among the anaerobes. However, two studies suggested that some of the acid-forming bacteria were more severely affected by the presence of heavy metals than the methanogens (Hickey et al. 1989; Lin 1993). Hickey et al. (1989) investigated the effects of $\mathrm{Cu}, \mathrm{Zn}$ and $\mathrm{Cd}$ on biomethane production and on hydrogen and carbon monoxide levels, and found that some trophic groups of organisms within the anaerobic consortia of digesters might be more severely inhibited by a pulsed addition of heavy metals than the methanogenic populations. Lin (1993) also demonstrated that $\mathrm{Cu}$ and $\mathrm{Zn}$ were more toxic to acidogens than to methanogens. Jain et al. (1992) have investigated the absorption of iron, copper, cadmium, nickel, lead, zinc, manganese and cobalt by Azolla pinnata $\mathrm{R}$.Br and Lemna minor L., and subsequent utilization of this biomass for production of biogas (biomethane). Whilst iron or manganese did not have any toxic effect on the anaerobic fermentation of Azolla and Lemna, copper, cobalt, lead and zinc showed toxicity. Jain et al. (1992) noted that at low concentrations, cadmium and nickel had a favourable effect on the rate of biogas production and its biomethane content, but with increase in concentrations, the rate of biogas production and biomethane content decreased. Leighton and Forster (1998) reported that nickel and lead had the greatest impact on biogas production. On the basis of the VFA production, nickel and lead appeared to act immediately on acidogenesis and more slowly on the methanogenic bacteria. On the other hand, Lin and Chen (1999) reported that biogranules in the methanogenesis process exhibited a higher sensitivity to metal toxicity than in the acidogenesis process. However, the HPr- and HBu-degrading acidogens in the biogranules from the methanogenesis process were more sensitive in activity to copper than HAc-degrading methanogens. Besides, long HRT increased the toxicity resistance of HAc-degrading methanogens but decreased that of HPr- and $\mathrm{HBu}$-degrading acidogens. On a related scale of research, Zayed and Winter (2000) have used a whey solution as substrate for biomethane production in an anaerobic fixed-bed reactor. At a hydraulic retention time of 10 days, equivalent to a space loading of $3.3 \mathrm{~kg} \mathrm{~m}^{-3}$ day $^{-1}, 90 \%$ of the chemical oxygen demand was converted to biogas. Only a little propionate remained in the effluent. Toxicity tests with either copper chloride, zinc chloride or nickel chloride were also performed on effluent from the reactor. Results indicated that a $50 \%$ inhibition of methanogenesis occurred in the presence of $\geq 10 \mathrm{mg} \mathrm{CuCl} \mathrm{L}^{-1} \geq 40 \mathrm{mg} \mathrm{ZnCl}_{2} \mathrm{~L}^{-1}$ and $\geq 60 \mathrm{mg} \mathrm{NiCl}{ }_{2} \mathrm{~L}^{-1}$, respectively. Zayed and Winter (2000) also noted that after an exposure to $\mathrm{Cu}^{2+}, \mathrm{Zn}^{2+}$ or $\mathrm{Ni}^{2+}$ ions for 12 days, a complete recovery of methanogenesis by equimolar sulphide addition was possible upon prolonged incubation. Though recovery failed for copper chloride concentrations $\geq 40 \mathrm{mg} \mathrm{L}^{-1}$, the simultaneous addition of sulphide with the three heavy metal salts only slightly retarded the methanogenic reactions and the same amount of biomethane as in non-inhibited controls was reached either 1 day (40 $\mathrm{mg} \mathrm{ZnCl}_{2} \mathrm{~L}^{-1}$ ) or 2 days later (10 mg $\mathrm{CuCl}_{2} \mathrm{~L}^{-1}$ ). Zayed and Winter (2000) hypothesized that sulphide presumably precipitated the heavy metals as metal sulphides and by this means prevented heavy metal toxicity to the methanogens.

\section{Beneficial effects}

Other researchers have explicitly reported that the addition of certain metals to the feed materials in anaerobic digestion processes has been found to increase the biogas (biomethane) production. It has been demonstrated by Kim et al. (2002) that efficient removal of propionate at high levels of VFA required supplementation of $\mathrm{Ca}, \mathrm{Fe}$, $\mathrm{Ni}$, and $\mathrm{Co}$ in a thermophilic non-mixed reactor. 
Anaerobic co-digestion of cattle manure with potato waste was improved in terms of biogas production by the addition of heavy metals at $2.5 \mathrm{mg} \mathrm{L}^{-1}$ rather than $5 \mathrm{mg} \mathrm{L}^{-1}$, with the greatest increase from $\mathrm{Cd}^{2+}$ followed by $\mathrm{Ni}^{2+}$ then $\mathrm{Zn}^{2+}$ (Kumar et al. 2006). However, methanogenic cell concentrations in excess of 1.32, 1.13, $0.12,4.8$, and $30 \mathrm{~g} \mathrm{~L}^{-1}$ have been found to be limited by $\mathrm{Fe}$ at a concentration of $5 \mathrm{mg} \mathrm{L}^{-1}, \mathrm{Zn}$ at $1 \mathrm{mg} \mathrm{L}^{-1}, \mathrm{Cu}$ at $0.1 \mathrm{mg} \mathrm{L}^{-1}, \mathrm{Ni}$ at $1.2 \mathrm{mg} \mathrm{L}^{-1}$ and $\mathrm{Co}$ at $4.8 \mathrm{mg} \mathrm{L}^{-1}$, respectively (Zhang et al. 2003). It is much believed that these metals are used by the organisms as part of their enzyme structure. Chen et al. (2004) have developed and characterized a novel phosphodiesterase enzyme in Methanococcus jannaschii which has an absolute requirement for divalent metal ions, with $\mathrm{Ni}^{2+}$ and $\mathrm{Mn}^{2+}$ being the most effective. Nickel sites in the acetyl-CoA decarboxylase/synthase enzyme complex have been identified. This enzyme seemed to have an important role in the conversion of acetate to biomethane (Funk et al. 2004). Patel et al. (1993) examined the effect of $\mathrm{FeCl}_{3}, \mathrm{NiCl}_{2}, \mathrm{CoCl}_{2}$, $\mathrm{CuCl}_{2}$, and $\mathrm{ZnCl}_{2}$, on anaerobic digestion of water hyacinth-cattle dung and concluded that $\mathrm{FeCl}_{3}$ caused a more than $60 \%$ increase in biogas production with high biomethane content. Gonzalez-Gil et al. (1999) noted that when metals were added in a pulse mode to methylotrophic-methanogenic biomass, three biomethane production rate phases were observed. Increased concentrations of $\mathrm{Ni}$ and $\mathrm{Co}$ actually accelerated the initial exponential and final arithmetic increases in the biomethane production rate and reduced the temporary decrease in the rate. More interestingly, when $\mathrm{Ni}$ and Co were added continuously, the temporary decrease phase was eliminated and the exponential biomethane production rate increased. Gonzalez-Gil et al. (1999) hypothesized that the temporary decrease in the biomethane production rate and the final arithmetic increase in the biomethane production rate were due to micronutrient limitations. It was also suspected that the precipitation-dissolution kinetics of metal sulphides might have played an important role in the bioavailability of these compounds. Bartacek et al. (2008) have investigated the influence of cobalt speciation on the toxicity of cobalt to methylotrophic methanogenesis in anaerobic granular sludge. The cobalt speciation had been studied with three different media that contained varying concentrations of complexing ligands namely carbonates, phosphates and ethylenediaminetetraacetic acid (EDTA). Results indicated that the average concentration of cobalt required for $50 \%$ inhibition of methanogenic activity for free $\mathrm{Co}^{2+}$ in the three sets of measurements was $13 \mu \mathrm{mol} \mathrm{L}{ }^{-1}$. Complexation (and precipitation) with EDTA, phosphates and carbonates was shown to have significantly decreased the toxicity of cobalt on methylotrophic methanogenesis. As a result, it was proposed that free cobalt toxicity to granular sludge could be estimated based on the equilibrium-free cobalt concentration.

\section{Effects on sludge granulation}

The UASB reactor has been used increasingly in recent years to treat a variety of industrial wastes and municipal wastes (Akila and Chandra 2007; Elmitwalli and Otterpohl 2007; Luostarinen and Rintala 2007; Kotsopoulos et al. 2006; Yu and Mu 2006; Yoneyama et al. 2006; Nadais et al. 2005). The UASB process involves the anaerobic degradation of organic wastes using biomass, which gradually aggregates to produce granules (Schmidt and Ahring 1996). The UASB process is attractive because of its compactness, low operational cost, low sludge production, and production of biomethane. More than 1,000 UASB units are currently being operated all over the world. The application of UASB reactors for the treatment of highstrength industrial wastewater containing easily hydrolyzed substrates such as sugar industry wastes, distillery wastes, and brewery wastes had been successful.

In the absence of a support medium in UASB reactors, different syntrophic groups closely associate to form roughly spherically shaped clusters known as granules. Granules may range from 0.1 to $5 \mathrm{~mm}$ in size and are differentiated from flocculated sludge by higher shear strength. A granule can be functionally described as concentric layers of near-spherical biofilm possessing different bacterial trophic groups (Tiwari et al. 2006). Each of the trophic groups of bacteria performs its respective role in the degradation of wastewater, producing biomass and exocellular polymers (ECPs) in its vicinity, which helps other trophic groups to attach and derive nutrition (Tiwari et al. 2006). However, in reality, such layers may or may not exist within a granule. However, a few studies have indicated the existence of such segregated layers of microbial populations inside a granule. The granulation process is commonly believed to be sensitive to the sudden change of environmental and operational conditions. Factors governing granulation have been extensively studied on a variety of wastewaters. These factors include $\mathrm{pH}$ and alkalinity, temperature, strength and composition of wastewater, reactor hydrodynamics, presence of metal ions and trace metals, presence of polymers, microbial ecology, and production of exo-cellular polymeric substances by anaerobic bacteria (Tiwari et al. 2006). Microbial granulation involves different trophic bacterial groups, and physico-chemical and microbiological interactions. Many factors contribute in one form or another to the granulation process. Granulation may be initiated by bacterial adsorption and adhesion to inert matter, inorganic precipitates and/or to each other through physico-chemical interactions and syntrophic relationships. These substances serve as 
initial precursors (carriers or nuclei) for new bacterial growth (Uemura and Harada 1995).

The trace element requirement of anaerobic microorganisms is specific because many cobalt-, nickel-, and ironcontaining enzymes are involved in the biochemistry of fermentation and biomethane production (Tiwari et al. 2006). Therefore, the lack of some key trace metals may severely limit the overall anaerobic conversion process and granulation. The toxicity of heavy metal towards anaerobic digestion is independent of total metal concentration in the digester but depends on the concentration of free metal species in the sludge. Active, inactive, and dead biomass are capable of binding and accumulating high quantities of heavy metals (Tiwari et al. 2006). Some trophic groups or organisms within the anaerobic consortia in the digesters may be more severely inhibited by a pulse addition of toxic heavy metals than are methanogenic populations (Hickey et al. 1989). Fang (1997) studied the toxicity of five heavy metals commonly found in the electroplating effluent on the activity of anaerobic biogranules. Biogranules were sampled from UASB reactors treating four types of wastewaters containing separately acetate, propionate, starch and benzoate as the sole substrate. All reactors were operated at $37^{\circ} \mathrm{C}$ for over 6 months at a loading rate of $10 \mathrm{~g} \mathrm{COD} \mathrm{L}^{-1} \mathrm{day}^{-1}$. It was found that the methanogenic activity of biogranules treating each type of wastewater decreased with the increase of metal concentration. The toxicity of each metal to the biogranules was measured by the reduction of methanogenic activity of biogranules in serum vials, as compared to the controls. It was found that acetate- and propionate-degrading biogranules exhibited higher resistance to electroplating metals than the starchand benzoate-degrading ones. Results from the study of Fang (1997) implied that heavy metals from electroplating effluent inhibited the biological activity of fermentative/ acidogenic bacteria more than those of methanogens and acetogens. For the latter two groups of bacteria, the toxicity of the heavy metals was in the following descending order: $\mathrm{Zn}>\mathrm{Ni}>\mathrm{Cu}>\mathrm{Cd}>\mathrm{Cr}$.

Iron is essential for the growth of almost all microorganisms. The basic physiological function of $\mathrm{Fe}$ is as a cofactor for some proteins, most of which are related to energy metabolism. Yu et al. (2000) also performed experiments in parallel using six identical UASB reactors to examine the effects of iron $\left(\mathrm{Fe}^{2+}\right)$ on sludge granulation during start-up. It was found that the introduction of $\mathrm{Fe}^{2+}$ at concentrations of 300 and $450 \mathrm{mg} \mathrm{L}^{-1}$ enhanced the granulation process in UASB reactors, while lower dosage of $\mathrm{Fe}^{2+}\left(150 \mathrm{mg} \mathrm{L}^{-1}\right)$ had little effect on the sludge granulation. Interestingly, the specific activity of granules decreased with increasing $\mathrm{Fe}^{2+}$ concentration in the feed, and for high $\mathrm{Fe}^{2+}$ dosages, a large amount of minerals was deposited within the granules, and FeS and the compounds formed by iron and exopolysaccharide polymers were the main precipitates. Along with the significant decrease in the water content in granules, the possible toxicity of highlevel $\mathrm{Fe}^{2+}$ accumulated inside granules had reduced the overall bacterial specific activity. Recently, Vlyssides et al. (2009) have also investigated the effect of ferrous ion addition on the granularity of an UASB reactor operated for 3 months at a 20-h HRT at organic loads from 1.4 to $10.0 \mathrm{~g} \mathrm{COD} \mathrm{L}^{-1} \mathrm{day}^{-1}$. It was deduced that the addition of ferrous iron could induce a stable and excellent COD conversion rate, and the enhancement of the performance of one of the UASB reactor could be accredited to the mean granule diameter increase as well as to the sludge bed porosity decrease. In conclusion, the study of Vlyssides et al. (2009) indicated that the addition of iron to the first UASB reactor had a pronounced effect on the quality of the granular sludge. Still on the assessment of COD removal and granular sludge improvement research tone, Sondhi et al. (2010) concluded a study on the effect of aluminium on agglomeration in the sludge bed and COD removal efficiency in laboratory-scale UASB reactors treating low-strength synthetic wastewater (approximately 665-738 $\mathrm{mg} \mathrm{L}^{-1}$ of COD). An adverse effect was observed on granulation when $300 \mathrm{mg} \mathrm{L}^{-1}$ aluminium chloride was added only during the startup, and the effect continued even after it was discontinued. A lower concentration of aluminium chloride $\left(50 \mathrm{mg} \mathrm{L}^{-1}\right)$ added for 30 days after the reactors reached steady-state did not affect the COD removal efficiency, but adversely affected the growth of agglomerates and caused temporary degeneration of existing agglomerates. The adverse effect of aluminium appeared to stem from the precipitation of aluminium hydroxide on the surfaces of agglomerates and the effect of aluminium on agglomeration was shown to be a function of influent strength.

\section{Effects on anaerobic degradation of pollutants}

Studies on the effect of metals on organic pollutant biodegradation are not extensive but demonstrate that metals have the potential to inhibit pollutant biodegradation under both aerobic and anaerobic conditions (Sandrin and Maier 2003). A number of studies show a pattern of metal toxicity in which low metal concentrations stimulate activity until a maximum level of stimulation is reached after which metal toxicity increases with increasing metal concentration. It should be noted that all these studies used consortia not single isolates. Therefore, it is likely that this pattern is a result of differential toxicity effects, wherein a second population more sensitive to metal stress competes in some way with the population expressing the activity of interest. Inhibition of the second population reduces competition for resources needed by the first population. 
Hazardous halogenated aromatic compounds which have been used by agriculture and industry and discharged into the environment for several decades often accumulate in anaerobic sediments, soils, and aquifers. Anaerobic bioremediation has been proposed as an inexpensive method for in situ removal of organic contaminants in the environment, and a number of studies (Table 2) have demonstrated the promise of the anaerobic biotechnology in the degradation of organic contaminants. However, heavy metal contamination from both natural (erosion, fires, leaching, volcanic activity, and microbial transformation) and anthropogenic (industrial waste, dumping of sewage, burning of fossil fuels, etc.) sources also results in the accumulation of metals in anoxic environmental niches. The effect of added $\mathrm{Cd}^{2+}, \mathrm{Cu}^{2+}, \mathrm{Cr}^{6+}$, or $\mathrm{Hg}^{2+}$ at $0.01-100 \mathrm{mg} \mathrm{L}^{-1}$ on metabolism in anaerobic bacterial consortia which degrade 2-chlorophenol (2CP), 3-chlorobenzoate (3CB), phenol, and benzoate was examined by Kuo and Genthner (1996). In this work, three effects were observed. These included extended acclimation periods (0.1-2.0 $\left.\mathrm{mg} \mathrm{L}^{-1}\right)$, reduced dechlorination or biodegradation rates $\left(0.1-2.0 \mathrm{mg} \mathrm{L}^{-1}\right)$ and failure to dechlorinate or biodegrade the target compound $\left(0.5-5.0 \mathrm{mg} \mathrm{L}^{-1}\right) .3 \mathrm{CB}$ biodegradation was most sensitive to $\mathrm{Cd}^{2+}$ and $\mathrm{Cr}^{6+}$. Biodegradation of benzoate and phenol was most sensitive to $\mathrm{Cu}^{2+}$ and $\mathrm{Hg}^{2+}$, respectively. Adding $\mathrm{Cr}^{6+}$ at $0.01 \mathrm{mg}$ $\mathrm{L}^{-1}$ increased biodegradation rates of phenol $(177 \%)$ and benzoate $\left(169 \%\right.$ ), while $\mathrm{Cd}^{2+}$ and $\mathrm{Cu}^{2+}$ at $0.01 \mathrm{mg} \mathrm{L}^{-1}$ enhanced biodegradation rates of benzoate $(185 \%)$ and 2CP (168\%), respectively. Interestingly, with $\mathrm{Hg}^{2+}$ at $1.0-2.0 \mathrm{mg} \mathrm{L}^{-1}, \quad 2 \mathrm{CP}$ and $3 \mathrm{CB}$ were biodegraded $133-154 \%$ faster than controls after an extended acclimation period, suggesting adaptation to $\mathrm{Hg}^{2+}$. Metal ions were added at inhibitory, but sublethal, concentrations to investigate effects on metabolic intermediates and end products. Kuo and Genthner (1996) also observed that phenol accumulated to concentrations higher than those in controls only in the $2 \mathrm{CP}$ consortium with added $\mathrm{Cu}^{2+}$ at $1.2 \mathrm{mg} \mathrm{L}^{-1}$ but was subsequently degraded. There was no effect on benzoate, and little effect on acetate intermediates was observed. In most cases, biomethane yields were reduced by $23-97 \%$. Thus, dehalogenation, aromatic degradation, and methanogenesis in these anaerobic consortia showed differential sensitivities to the heavy metal ions added. These data indicated that the presence of heavy metals could affect the outcome of anaerobic bioremediation of aromatic pollutants. In addition, a potential exists to use combinations of anaerobic bacterial species to bioremediate sites contaminated with both heavy metals and aromatic pollutants.

Such an indirect mode of toxicity has also been implicated in metal inhibition of anaerobic biodegradation of trinitrotoluene (TNT) metabolites (Roberts et al. 1998).
In the study from Roberts et al. (1998), copper, zinc, and lead did not affect establishment of anaerobic conditions in bioreactors containing soil slurries nor did these metals impact loss of the parent TNT compound. However, the subsequent removal of TNT degradation intermediates was reduced by each of the metals. For example, lead (total concentrations $>1,000 \mathrm{mg} \mathrm{kg}^{-1}$ ) delayed degradation of a TNT biodegradation intermediate (2,4-diamino-6-nitrotoluene [2,4-DANT]) by as many as 9 days. Zinc $(1,500 \mathrm{mg}$ total zinc $/ \mathrm{kg}$ ) delayed degradation of the same intermediate by 8 days. Copper $\left(4,000\right.$ and $8,000 \mathrm{mg}$ total copper $\left.\mathrm{kg}^{-1}\right)$ completely inhibited removal of this intermediate. Clearly, when considering the impact of metals on organic biodegradation, the effects of metals on populations other than degraders of the parent compound must also be considered. Aziz et al. (2004) examined the inhibitory effects of zinc on the acidogenic-anaerobic biotreatment using anaerobic toxicity assay test and anaerobic sequencing batch reactor. The specificity of this study was that experiments were conducted in two phases. The first phase consisted in using synthetic wastewater alone and the second phase tested synthetic wastewater containing nitrobenzene as the test organic pollutant (Lang et al. 2007). With respect to the health of the anaerobic digestion processes, Aziz et al. (2004) found that zinc could significantly inhibit the acidogenesis process with concentration higher than $12.5 \mathrm{mg} \mathrm{L}^{-1}$, and the production of VFA was inhibited progressively with increasing zinc concentrations. It was observed that propionic acid was most severely affected followed by valeric acid, butyric acid and acetic acid with the increasing concentration of zinc. Quite expectedly, the increasing concentrations of zinc resulted in decreased removal efficiencies of organics from wastewaters, removal efficiencies of nitrobenzene were almost 100 and $90 \%$ when zinc concentrations were 0 and $50 \mathrm{mg} \mathrm{L}^{-1}$, respectively. This indicated that the acidogenic process was still able to remove nitrobenzene effectively. In the acidogenic stage, nitrobenzene was converted to aniline and was found to be less inhibitory than nitrobenzene. With regard to the methanogenic performance, the anaerobic toxicity assays indicated up to $50 \%$ inhibition on biogas production at $100 \mathrm{mg} \mathrm{L}^{-1}$ of nitrobenzene and $50 \mathrm{mg} \mathrm{L}^{-1}$ of zinc.

A small number of studies have been conducted in anaerobic soil and sediment systems. Work in soil systems suggests that soil type influences metal toxicity and the anaerobic digestion processes to variable extents. The extensive work of Capone et al. (1983) may be here used to exemplify and support the latter argument. Capone et al. (1983) examined the effects of several metals on microbial biomethane, carbon dioxide, and sulphide production and microbial ATP in sediments from Spartina alterniflora communities. It was found that biomethane evolution was 
Table 2 Application of anaerobic digestion processes in organic contaminant degradation

\begin{tabular}{|c|c|c|c|}
\hline $\begin{array}{l}\text { Organic contaminant/ } \\
\text { contaminant class }\end{array}$ & $\begin{array}{l}\text { Features of contaminant/ } \\
\text { contaminant class }\end{array}$ & Experimental conditions and inferences on biodegradation & Reference \\
\hline Meta-substituted halobenzoates & $\begin{array}{l}\text { Organohalides are } \\
\text { environmentally relevant } \\
\text { compounds that can be degraded } \\
\text { by aerobic and anaerobic } \\
\text { microorganisms. The } \\
\text { denitrifying Thauera } \\
\text { chlorobenzoica is capable of } \\
\text { degrading halobenzoates as sole } \\
\text { carbon and energy source under } \\
\text { anaerobic conditions. }\end{array}$ & $\begin{array}{l}\text { LC-MS/MS-based coenzyme A }(\mathrm{CoA}) \text { thioester analysis } \\
\text { revealed that 3-chloro- or 3-bromobenzoate were } \\
\text { preferentially metabolized via non-halogenated CoA } \\
\text { ester intermediates of the benzoyl-CoA degradation } \\
\text { pathway. In contrast, 3-fluorobenzoate, which does not } \\
\text { support growth, was converted to dearomatized } \\
\text { fluorinated CoA ester dead-end products. It appeared } \\
\text { that the presence of a halobenzoate-specific carboxylic } \\
\text { acid CoA ligase rather than a specific reductive } \\
\text { dehalogenase governed whether an aromatic compound } \\
\text { degrading anaerobe would be capable of metabolizing } \\
\text { halobenzoates }\end{array}$ & $\begin{array}{l}\text { Kuntze } \\
\text { et al. } \\
\text { (2011) }\end{array}$ \\
\hline $\begin{array}{l}\text { 2,4-dichlorophenoxyacetic acid } \\
(2,4-\mathrm{D})\end{array}$ & $\begin{array}{l}\text { 2,4-D is the third-most widely } \\
\text { used herbicide in North America } \\
\text { and the most widely used } \\
\text { herbicide in the world. It is the } \\
\text { active ingredient in several } \\
\text { formulations of herbicides } \\
\text { recommended for the control of } \\
\text { broadleaf weeds. It has major } \\
\text { uses in agriculture crops, } \\
\text { forestry, turf, non-crop and } \\
\text { aquatic weeds }\end{array}$ & $\begin{array}{l}\text { The role of the humic model compound, anthraquinone- } \\
\text { 2,6-disulfonate (AQDS), in the anaerobic reductive } \\
\text { dechlorination of 2,4-D by the Fe(III)- and humic } \\
\text { substances (HS)-reducing bacterium, Comamonas } \\
\text { koreensis strain CY01 was investigated. } \\
\text { Results suggested that 2,4-D reductive dechlorination by } \\
\text { CY01 strain was a biochemical process that oxidizes the } \\
\text { electron donors and transfers the electron to the } \\
\text { acceptors through redox mediator, AQDS. }\end{array}$ & $\begin{array}{l}\text { (Wang } \\
\text { et al. } \\
\text { 2009a, b) }\end{array}$ \\
\hline $\begin{array}{l}\text { Brominated flame retardants } \\
\text { (BFRs) }\end{array}$ & $\begin{array}{l}\text { BFRs are chemicals used for fire } \\
\text { prevention. Concern has been } \\
\text { growing over the heavy use of } \\
\text { some of the BFRs, since their } \\
\text { levels in the environment have } \\
\text { increased in recent decades. } \\
\text { BFRs are generally } \\
\text { hydrophobic, and fugacity } \\
\text { models have shown that large } \\
\text { proportions of a major class of } \\
\text { BFRs (polybrominated diphenyl } \\
\text { ethers, PBDEs) released to the } \\
\text { environment will end up in soil } \\
\text { or sediment }\end{array}$ & $\begin{array}{l}\text { Biodegradation kinetics in aerobic and anaerobic soil of } \\
\text { the following brominated flame retardants: } 2,4,4^{\prime}- \\
\text { tribromodiphenyl ether (BDE 28), decabromodiphenyl } \\
\text { ether (BDE 209), tetrabromobisphenol A (TBBPA), 1,2- } \\
\text { dibromo-4-(1,2-dibromoethyl)cyclohexane (TBECH), } \\
\text { 2,4,6-tribromophenol ( } 246 \mathrm{BrPh}) \text {, and } \\
\text { hexabromobenzene (HxBrBz); and for comparison, the } \\
\text { biodegradation of the chlorinated compounds } 2,4,4^{\prime}- \\
\text { trichlorodiphenyl ether (CDE } 28), 2,4,6 \text {-trichlorophenol } \\
\text { (246ClPh), hexachlorobenzene (HxClBz), and } \\
2,2^{\prime}, 4,4^{\prime}, 5,5^{\prime} \text {-hexachlorobiphenyl (PCB 153) were all } \\
\text { assessed. } \\
\text { In aerobic soil, BDE } 209 \text { showed no significant } \\
\text { degradation during the test period, but concentrations of } \\
\text { the other BFRs declined, with half-lives decreasing in } \\
\text { the following order: } \\
\text { BDE } 28>\text { TBBPA }>\text { TBECH }>\text { HxBrBz }>246 \mathrm{BrPh} \text {. } \\
\text { Declines in almost the same order were observed in } \\
\text { anaerobic soil: BDE } 28, \\
\text { BDE } 209>\text { TBBPA }>\mathrm{HxBrBz}>\mathrm{TBECH}>246 \mathrm{BrPh} \text {. }\end{array}$ & $\begin{array}{l}\text { Nyholm } \\
\text { et al. } \\
\text { (2010) }\end{array}$ \\
\hline Nonylphenol (NP) & $\begin{array}{l}\text { NP has increasingly attracted } \\
\text { attention because of its potential } \\
\text { to mimic the action of natural } \\
\text { hormones in vertebrates. It } \\
\text { results from the incomplete } \\
\text { biodegradation of nonylphenol } \\
\text { polyethoxylates (NPEOs), which } \\
\text { have been widely used as non- } \\
\text { ionic surfactants in industrial } \\
\text { processes and households. Both } \\
\text { NP and NPEOs are discharged } \\
\text { into the environment, mainly } \\
\text { due to incomplete removal in } \\
\text { wastewater treatment facilities }\end{array}$ & $\begin{array}{l}\text { Effects of various factors on the anaerobic degradation of } \\
\mathrm{NP} \text { and characterization of the structures of microbial } \\
\text { communities in mangrove sediments collected at five } \\
\text { sites along the Danshui River in northern Taiwan were } \\
\text { investigated. NP anaerobic degradation rate constants } \\
\left(\mathrm{k}_{1}\right) \text { and half-lives }\left(\mathrm{t}_{1 / 2}\right) \text { ranged from } 0.008 \text { to } 0.0131 / \\
\text { day and } 53.3 \text { to } 86.6 \text { days, respectively. The addition of } \\
\mathrm{NaCl}(1 \%, 2 \%) \text {, zero-valent iron }(10 \mathrm{~g} / \mathrm{L}) \text {, humic acid } \\
(0.5 \mathrm{~g} / \mathrm{L}), \text { cellulose }(0.96 \mathrm{mg} / \mathrm{L}) \text {, brij } 30(55 \mu \mathrm{M}) \text { and } \\
\text { brij } 35(91 \mu \mathrm{M}) \text { enhanced NP anaerobic degradation. }\end{array}$ & $\begin{array}{l}\text { Chang } \\
\text { et al. } \\
\text { (2009) }\end{array}$ \\
\hline
\end{tabular}


Table 2 continued

\begin{tabular}{|c|c|c|c|}
\hline $\begin{array}{l}\text { Organic contaminant/ } \\
\text { contaminant class }\end{array}$ & $\begin{array}{l}\text { Features of contaminant/ } \\
\text { contaminant class }\end{array}$ & Experimental conditions and inferences on biodegradation & Reference \\
\hline $\begin{array}{l}19 \text { micro-organic pollutants } \\
\text { including endocrine disrupting } \\
\text { chemicals (EDCs) and } \\
\text { pharmaceuticals and personal } \\
\text { care products (PPCPs) }\end{array}$ & $\begin{array}{l}\text { One essential issue of wastewater } \\
\text { reuse is the emerging problem of } \\
\text { micro-organic pollutants such as } \\
\text { EDCs and PPCPs. These } \\
\text { compounds are widely used by } \\
\text { humans and discharged into } \\
\text { wastewater via excretion by } \\
\text { urine and faeces. Since most } \\
\text { conventional wastewater } \\
\text { treatment plants are not } \\
\text { designed for removing these } \\
\text { micro-organic pollutants, their } \\
\text { treatment performances are } \\
\text { usually limited }\end{array}$ & $\begin{array}{l}\text { The occurrence and elimination of } 19 \text { micro-organic } \\
\text { pollutants including EDCs and PPCPs in a full-scale } \\
\text { anaerobic/anoxic/aerobic-membrane bioreactor process } \\
\text { was investigated. } 70 \% \text { removal of the target EDCs and } \\
50-100 \% \text { removal of most of the PPCPs were achieved, } \\
\text { with influent concentration ranging from ng/L to } \mu \mathrm{g} / \mathrm{L} \text {. } \\
\text { Three PPCPs, carbamazepine, diclofenac and sulpiride } \\
\text { were not well removed, with the removal efficiency } \\
\text { below } 20 \% \text {. }\end{array}$ & $\begin{array}{l}\text { Xue et al. } \\
\text { (2010) }\end{array}$ \\
\hline
\end{tabular}

inhibited both initially and overall by $\mathrm{CH}_{3} \mathrm{HgCl}, \mathrm{HgS}$, and $\mathrm{NaAsO}_{2}$. An initial inhibition was followed by a subsequent period of overall stimulation with $\mathrm{Hg}, \mathrm{Pb}, \mathrm{Ni}, \mathrm{Cd}$, and $\mathrm{Cu}$, all as chlorides, and with $\mathrm{ZnSO}_{4}, \mathrm{~K}_{2} \mathrm{CrO}_{4}$, and $\mathrm{K}_{2} \mathrm{Cr}_{2} \mathrm{O}_{7}$. The production of $\mathrm{CO}_{2}$ was generally less affected by the addition of metals, and inhibition was noted with $\mathrm{NaAsO}_{2}, \mathrm{CH}_{3} \mathrm{HgCl}$, and $\mathrm{Na}_{2} \mathrm{MoO}_{4}$. However, a minor stimulation of $\mathrm{CO}_{2}$ production occurred over the long term with chlorides of $\mathrm{Hg}, \mathrm{Pb}$, and Fe. All the more, sulphate reduction was inhibited in the short term by all metals tested and over the long term by all but $\mathrm{FeCl}_{2}$ and $\mathrm{NiCl}_{2}$. Interestingly, microbial biomass was decreased by $\mathrm{FeCl}_{2}$, $\mathrm{K}_{2} \mathrm{Cr}_{2} \mathrm{O}_{7}, \mathrm{ZnSO}_{4}, \mathrm{CdCl}_{2}$, and $\mathrm{CuCl}_{2}$ but remained generally unaffected by $\mathrm{PbCl}_{2}, \mathrm{HgCl}_{2}$ and $\mathrm{NiCl}_{2}$. Although the majority of metals produced an immediate inhibition of methanogenesis, for several metals this was only a transient phenomenon followed by an overall stimulation. The initial suppression of methanogenesis may be relieved by precipitation, complexation, or transformation of the metal possibly by methylation, with the subsequent stimulation resulting from a sustained inhibition of competing organisms like sulphate-reducing bacteria.

Much later, Pardue et al. (1996) examined the impact of cadmium on reductive dehalogenation of TCA in different soils. In microcosms containing two mineral-dominated soils, only $0.01 \mathrm{mg}$ solution-phase cadmium $\mathrm{L}^{-1}$ was required to inhibit reductive dehalogenation. In microcosms containing an organic matter-dominated soil, more than an order of magnitude higher cadmium concentration $(0.2 \mathrm{mg}$ solution-phase cadmium $\mathrm{L}^{-1}$ ) was required to inhibit dehalogenation. Furthermore, results showed that the dehalogenation pathway used was affected by the cadmium concentration. A single dehalogenation pathway was observed until the cadmium concentration neared the inhibitory concentration. At this point, a second degradation pathway was observed. Sediments have also been shown to mediate metal toxicity. The impact of metals on reductive dehalogenation of hexachlorobenzene (HCB) in a waste lagoon sediment co-contaminated with cadmium and lead has been investigated (Jackson and Pardue 1998). In this study, cadmium and lead inhibited reductive dehalogenation, but only when not bound to sediment material and present in the free, bioavailable form. Shortly after, Mishra et al. (1999) analysed the effect of selected heavy metals on biomethane production in three rice soils under flooded conditions in a laboratory incubation system. Much in phase with other observations reported in this review, Mishra et al. (1999) pointed out that the heavy metals behaved differently in their effect on methanogenesis in different soils and biomethane-producing bacteria. $\mathrm{Cd}, \mathrm{Cu}$ and $\mathrm{Pb}$ had been found to inhibit biomethane production in all the soils. Conversely $\mathrm{Zn}$ stimulated the methanogenic reactions in the alluvial soil, but inhibited these in laterite and acid sulphate soils. Still conversely to $\mathrm{Zn}, \mathrm{Cr}$ effectively inhibited biomethane production in the alluvial soil but stimulated it in laterite and acid sulphate soils. The stimulatory effect of $\mathrm{Zn}$ and the inhibitory effect of $\mathrm{Cr}$ on methanogenesis in alluvial soil were thereafter attributed to their stimulation or inhibition potential of the competing methanogenic bacterial populations which could alternately and preferentially adapt to the types and concentrations of heavy metals they were being exposed to.

\section{Suppressive effects on hydrogen production}

Anoxygenic photo-trophic bacteria produce hydrogen from biomass (i.e. biohydrogen) (Weaver et al. 1980) and 
a number of innovative research have been completed to date (Argun et al. 2009; Chong et al. 2009; Kapdan et al. 2009; Chen et al. 2008a, b; Jo et al. 2008; Pattra et al. 2008; Fan et al. 2006) in this emerging field of bioenergy generation using different reactor designs and vessels. This process of hydrogen photo-fermentation is strongly coupled with the photosynthetic electron transport system, through which the bacteria obtain energy (Weaver et al. 1980). Many electron carriers of the system, including cytochromes, are protein complexes containing Fe. Moreover, nitrogenase, the functional enzyme of hydrogen production in these bacteria, has been reported to contain $\mathrm{Fe}$ in each molecule (Ludden and Robert 1995). Ferredoxin, which is an electron carrier for nitrogenase also contains Fe. Because of the importance of $\mathrm{Fe}$ to the light energy utilization and hydrogen production system of anoxygenic photo-trophic bacteria, it is believed that the availability of $\mathrm{Fe}$ in the culture medium may greatly influence hydrogen production in these microorganisms during anaerobic and fermentative processes.

The effect of ferrous ion $\left(0-3.2 \mathrm{mg} \mathrm{L}^{-1}\right)$ on the photoheterotrophic hydrogen production was recently studied in batch culture using sodium lactate as substrate by Zhu et al. (2007). The results showed that hydrogen production by Rhodobacter sphaeroides was significantly suppressed when $\mathrm{Fe}^{2+}$ was limited, and that hydrogen production increased linearly with an increase in $\mathrm{Fe}^{2+}$ concentration in the range of $0-1.6 \mathrm{mg} \mathrm{L}^{-1}$ reaching a maximum at $2.4 \mathrm{mg} \mathrm{L}^{-1}$. When hydrogen production was suppressed in the above medium, a pH increase to 8.9 was observed, and the ratio of lactate utilized to total organic carbon removal was found to be increased, indicating that more soluble organic products were produced. Under the $\mathrm{Fe}^{2+}$ limited conditions, ferrous iron was also found to have a greater effect on hydrogen production by $R b$. sphaeroides than that by the anaerobic heterotrophic bacterium Clostridium butyricum. The study of Zhu et al. (2007) indicated that the ferrous ion could be a critical factor to affect photohydrogen production when $\mathrm{Fe}^{2+}$ was less than $2.4 \mathrm{mg} \mathrm{L}^{-1}$. So, it becomes important to make certain that sufficient $\mathrm{Fe}^{2+}$ is contained in substrates when photo-trophic anoxygenic bacteria are used as the hydrogen production carrier. However, when $\mathrm{FeSO}_{4} \cdot 7 \mathrm{H}_{2} \mathrm{O}$ is considered as the source of $\mathrm{Fe}^{2+}$, it should not be higher than $23.5 \mathrm{mg} \mathrm{L}^{-1}$ having an equivalent content of $3.2 \mathrm{mg} \mathrm{L}^{-1}$ of $\mathrm{Fe}^{2+}$ in order to avoid possible non-physiological effect such as coagulation effect. Later, Li and Fang (2007) investigated the toxicity of six electroplating metals on the $\mathrm{H}_{2}$-producing activity of a granular sludge sampled from an $\mathrm{H}_{2}$-producing upflow reactor treating sucrose-containing wastewater. The $\mathrm{H}_{2}$ production activities of the sludge were measured in serum vials using wastewater containing not just sucrose and proper nutrient, but also individual heavy metals at concentrations ranging $0-5,000 \mathrm{mg} \mathrm{L}^{-1}$. The relative toxicity to $\mathrm{H}_{2}$ production was found in the following order: $\mathrm{Cu}$ (most toxic) $\mathrm{Ni}>\mathrm{Zn}>\mathrm{Cr}>\mathrm{Cd}>\mathrm{Pb}$ (least toxic), and the $\mathrm{CI}_{50}$ values, at which the bioactivity of the sludge was reduced to $50 \%$ of the control, for individual heavy metals were $\mathrm{Cu}$

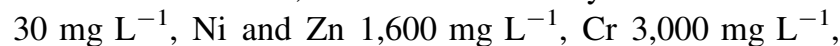
$\mathrm{Cd} 3,500 \mathrm{mg} \mathrm{L}^{-1}$, and $\mathrm{Pb}>5,000 \mathrm{mg} \mathrm{L}^{-1}$. Compared with literature data, $\mathrm{Li}$ and Fang (2007) reported that the $\mathrm{H}_{2}$-producing sludge had exhibited in general higher resistance to metal toxicity than methanogenic granular sludge. Lin and Shei (2008) also examined the effects of ionic $\mathrm{Cr}, \mathrm{Cu}$ and $\mathrm{Zn}$ on the fermentative hydrogen production. The hydrogen-producing natural mixed microflora dominated by the Clostridium species was cultivated from sewage sludge with sucrose. In general, the relative heavy metal toxicity to fermentative hydrogen production was $\mathrm{Zn}>$ $\mathrm{Cu}>\mathrm{Cr}$ and the microflora hydrogen production activity was reduced by $50 \%$ for a biomass that came into contact with $4.5 \mathrm{mg} \mathrm{Zn} \mathrm{L}^{-1}$, $6.5 \mathrm{mg} \mathrm{Cu} \mathrm{L}^{-1}$ and $60 \mathrm{mg} \mathrm{Cr} \mathrm{L}^{-1}$. However, low concentrations of $3 \mathrm{mg} \mathrm{Cu} \mathrm{L}^{-1}$ and $15 \mathrm{mg}$ $\mathrm{Cr} \mathrm{L}^{-1}$ resulted in peak $10-20 \%$ in hydrogen production stimulation with the threshold concentrations being $4 \mathrm{mg} \mathrm{Cu} \mathrm{L}^{-1}$ and $25 \mathrm{mg} \mathrm{Cr} \mathrm{L}^{-1}$, over which declining stimulation occurred. Wang and Wan (2008) investigated the effect of $\mathrm{Ni}^{2+}$ concentration ranging from 0 to 50 $\mathrm{mg} \mathrm{L}^{-1}$ on the fermentative hydrogen production by mixed cultures. Their results showed that at $35{ }^{\circ} \mathrm{C}$ and initial $\mathrm{pH}$ $7.0, \mathrm{Ni}^{2+}$ was able to enhance the hydrogen production rate with increasing $\mathrm{Ni}^{2+}$ concentration from 0 to $0.2 \mathrm{mg} \mathrm{L}^{-1}$, and enhance the hydrogen production potential and hydrogen yield with increasing $\mathrm{Ni}^{2+}$ concentration from 0 to $0.1 \mathrm{mg} \mathrm{L}^{-1}$.

\section{Conclusion}

The anaerobic digestion process includes three stages namely hydrolysis, acidification and biomethane production. At different points in the series of biochemical reactions in the latter stages, the anaerobic microorganisms are affected to variable extents by the substances present in the substrates. Among the several process stress factors which may limit the proper progress of the biochemical reactions, the effects of heavy metals on the anaerobic digestion process have been discussed in this review. The main inference from the above discussions is that heavy metals may be stimulatory, inhibitory, or even toxic to anaerobic 
reactions and the extents of these effects depend on the metal species and its concentration. A challenge which now requires further research is the study of the mechanistic aspects of the effects of heavy metals on the acetogenic and methanogenic stages of the anaerobic digestion process with the metallic ions analysed in standalone as well as competitive environments.

\section{References}

Akila G, Chandra TS (2007) Performance of an UASB reactor treating synthetic wastewater at low-temperature using coldadapted seed slurry. Process Biochem 42:466-471

Angelidaki I, Ahring BK (1994) Anaerobic digestion of manure at different ammonia loads: effect of temperature. Wat Res 28:727731

Angelidaki I, Alves M, Bolzonella D, Borzacconi L, Campos JL, Guwy AJ, Kalyuzhnyi S, Jenicek P, van Lier JB (2009) Defining the biomethane potential (BMP) of solid organic wastes and energy crops: a proposed protocol for batch assays. Wat Sci Technol 59:927-934

Appels L, Lauwers J, Degrève J, Helsen L, Lievens B, Willems K, Impe JV, Dewil R (2011) Anaerobic digestion in global bioenergy production: potential and research challenges. Renew Sust Energy Revi 15:4295-4301

Argun H, Kargi F, Kapdan IK (2009) Microbial culture selection for bio-hydrogen production from waste ground wheat by dark fermentation. Int J Hydrogen Energy 34:2195-2200

Aziz MA, Ng WN, Jinadasa KBSN (2004) Inhibitory effects of zinc on acidogenic-anaerobic biotreatment of wastewaters. IE(I) JEN 84:39-42

Bååth E (1989) Effects of heavy metals in soil on microbial processes and populations: a review. Wat Air Soil Pollut 47:335-379

Bartacek J, Fermoso FG, Baldo-Urrutia AM, van Hullebusch ED, Lens PNL (2008) Cobalt toxicity in anaerobic granular sludge: influence of chemical speciation. J Ind Microbiol Biotechnol 35:1465-1474

Bayer EA, Lamed R, Himmel ME (2007) The potential of cellulases and cellulosomes for cellulosic waste management. Curr Opin Biotechnol 18:237-245

Bertin L, Bettini C, Zanaroli G, Fraraccio S, Negroni A, Fava F (2012) Acclimation of an anaerobic consortium capable of effective biomethanization of mechanically-sorted organic fraction of municipal solid waste through a semi-continuous enrichment procedure. J Chem Technol Biotechnol 87:1312-1319

Bouallagui H, Haouari O, Touhami Y, Cheikh RB, Marouani L, Hamdi M (2004) Effect of temperature on the performance of an anaerobic tubular reactor treating fruit and vegetable waste. Process Biochem 39:2143-2148

Brady D, Duncan JR (1994) Binding of heavy metals by the cell walls of Saccharomyces cerevisiae. Enzym Microbiol Technol 16:633638

Capone DG, Reese DD, Kiene RP (1983) Effects of metals on methanogenesis; sulfate reduction; carbon dioxide evolution; and microbial biomass in anoxic salt marsh sediments. Appl Environ Microbiol 45:1586-1591

Chandra R, Venkata Mohan S (2011) Microalgal community and their growth conditions influence biohydrogen production during integration of dark-fermentation and photo-fermentation processes. Int J Hydrogen Energy 36:12211-12219
Chang BV, Lu ZJ, Yuan SY (2009) Anaerobic degradation of nonylphenol in subtropical mangrove sediments. J Hazard Mater 165:162-167

Chen SF, Yakunin AF, Kuznetsova E, Busso D, Pufan R, Proudfoot M, Kim R, Kim SH (2004) Structural and functional characterization of a novel phosphodiesterase from Methanococcus jannaschii. J Biol Chem 279:31854-31862

Chen Y, Cheng JJ, Creamer KS (2008a) Inhibition of anaerobic digestion process: a review. Bioresour Technol 99:4044-4064

Chen SD, Lee KS, Lo YC, Chen WM, Wu JF, Lin CY, Chang JS (2008b) Batch and continuous biohydrogen production from starch hydrolysate by Clostridium species. Int $\mathrm{J}$ Hydrogen Energy 33:1803-1812

Chong ML, Rahim RA, Shirai Y, Hassan MA (2009) Biohydrogen production by Clostridium butyricum EB6 from palm oil mill effluent. Int J Hydrogen Energ 34:764-771

Chynoweth DP, Owens JM, Legrand R (2001) Renewable methane from anaerobic digestion of biomass. Renewable Energy 22:1-8

Cirne DG, Paloumet X, Bjornsson L, Alves MM, Mattiasson B (2007) Anaerobic digestion of lipid-rich waste: effects of lipid concentration. Renewable Energy 32:965-975

Codina JC, Ascensión Muñoz M, Cazorla FM, Pérez-García A, Moriñigo MA, De Vicente A (1998) The inhibition of methanogenic activity from anaerobic domestic sludges as a simple toxicity bioassay. Wat Res 32:1338-1342

Colussi I, Cortesi A, Della Vedova L, Gallo V, Cano Robles FK (2009) Start-up procedures and analysis of heavy metals inhibition on methanogenic activity in EGSB reactor. Bioresour Technol 100:6290-6294

Demirel B, Scherer P (2011) Trace element requirements of agricultural biogas digesters during biological conversion of renewable biomass to methane. Biomass Bioenergy 35:992-998

Demirel B, Yenigun O (2004) Anaerobic acidogenesis of dairy wastewater: the effects of variations in hydraulic retention time with no pH control. J Chem Technol Biotechnol 79:755-760

Demirel B, Yenigün O (2002) Two-phase anaerobic digestion processes: a review. J Chem Technol Biotechnol 77:743-755

El-Mashad HM, Zeeman G, Van Loon WKP, Bot GPA, Lettinga G (2004) Effect of temperature and temperature fluctuation on thermophilic anaerobic digestion of cattle manure. Bioresour Technol 95:191-201

Elmitwalli TA, Otterpohl R (2007) Anaerobic biodegradability and treatment of grey water in upflow anaerobic sludge blanket (UASB) reactor. Wat Res 41:1379-1387

Fan KS, Kan NR, Lay JJ (2006) Effect of hydraulic retention time on anaerobic hydrogenesis in CSTR. Bioresour Technol 97:84-89

Fang HHP (1997) Inhibition of bioactivity of UASB biogranules by electroplating metals. Pure Appl Chem 69:2425-2429

Fang HHP, Chan OC (1997) Toxicity of electroplating metals on benzoate-degrading granules. Environ Technol 18:93-99

Fang HHP, Hui HH (1994) Effect of heavy metals on the methanogenic activity of starch-grading granules. Biotechnol Lett 16:10911096

Fang HHP, Yu HQ (2000) Effect of HRT on mesophilic acidogenesis of dairy wastewater. J Environ Eng 126:1145-1148

Fantozzi F, Buratti C (2009) Biogas production from different substrates in an experimental continuously stirred tank reactor anaerobic digester. Bioresour Technol 100:5783-5789

Ferrer I, Ponsá S, Vázquez F, Font X (2008) Increasing biogas production by thermal $\left(70{ }^{\circ} \mathrm{C}\right)$ sludge pre-treatment prior to thermophilic anaerobic digestion. Biochem Eng J 42:186-192

Funk T, Gu WW, Friedrich S, Wang HX, Gencic S, Grahame DA, Cramer SP (2004) Chemically distinct Ni sites in the A-cluster in subunit beta of the acetyl-CoA decarbonylase/synthase complex 
from Methanosarcina thermophila:NiL-edge absorption and X-ray magnetic circular dichroism analyses. J Am Chem Soc 126:88-95

Giotta L, Agostiano A, Italiano F, Milano F, Trotta M (2006) Heavy metal ion influence on the photosynthetic growth of Rhodobacter sphaeroides. Chemosphere 62:1490-1499

Glick BR (2003) Phytoremediation: synergistic use of plants and bacteria to clean up the environment. Biotechnol Adv 21:383-393

Gonzalez-Gil G, Kleerebezem R, Lettinga G (1999) Effects of nickel and cobalt on kinetics of methanol conversion by methanogenic sludge as assessed by on-line $\mathrm{CH} 4$ monitoring. Appl Environ Microbiol 65:1789-1793

Gonzalez-Silva BM, Briones-Gallardo R, Razo-Flores E, Celis LB (2009) Inhibition of sulfate reduction by iron; cadmium and sulfide in granular sludge. J Hazard Mater 172:400-407

Hartmann H, Ahring BK (2005) Anaerobic digestion of the organic fraction of municipal solid waste: influence of co-digestion with manure. Wat Res 39:1543-1552

Hickey RF, Vaderwielen J, Switzenbaum MS (1989) The effect of heavy metals on methane production and hydrogen and carbon monoxide levels during batch anaerobic sludge digestion. Wat Res 23:207-218

Jackson WA, Pardue JH (1998) Assessment of metal inhibition of reductive dechlorination of hexachlorobenzene at a superfund site. Environ Toxicol Chem 17:1441-1446

Jackson-Moss CA, Duncan JR, Cooper DR (1989) The effect of calcium on anaerobic digestion. Biotechnol Lett 11:219-224

Jain SK, Gujral GS, Jha NK, Vasudevan P (1992) Production of biogas from Azolla pinnata R.Br and Lemna minor L.: effect of heavy metal contamination. Bioresour Technol 41:273-277

Jeong E, Kim HW, Nam JY, Shin HS (2010) Enhancement of bioenergy production and effluent quality by integrating optimized acidification with submerged anaerobic membrane bioreactor. Bioresour Technol 101:7-12

Jo JH, Lee DS, Park D, Park JM (2008) Biological hydrogen production by immobilized cells of Clostridium tyrobutyricum JM1 isolated from a food waste treatment process. Bioresour Technol 99:6666-6672

Kapdan IK, Kargi F, Oztekin R, Argun H (2009) Bio-hydrogen production from acid hydrolyzed wheat starch by photofermentation using different Rhodobacter sp. Int J Hydrogen Energy 34:2201-2207

Kavamura VN, Esposito E (2010) Biotechnological strategies applied to the decontamination of soils polluted with heavy metals. Biotechnol Adv 28:61-69

Khanal SK (2008) Overview of anaerobic biotechnology, Chapter 1, In: anaerobic biotechnology for bioenergy production: principles and applications, Wiley and Blackwell Publishing, pp 1-27

Kim M, Ahn YH, Speece RE (2002) Comparative process stability and efficiency of anaerobic digestion: mesophilic versus thermophilic. Wat Res 36:4369-4385

Kim JK, Oh BR, Chun YN, Kim SW (2006) Effects of temperature and hydraulic retention time on anaerobic digestion of food waste. J Biosci Bioeng 102:328-332

Kotsopoulos TA, Zeng RJ, Angelidaki I (2006) Biohydrogen production in granular up-flow anaerobic sludge blanket (UASB) reactors with mixed cultures under hyper-thermophilic temperature $\left(70^{\circ} \mathrm{C}\right)$. Biotechnol Bioeng 94:296-302

Kumar A, Miglani P, Gupta RK, Bhattacharya TK (2006) Impact of $\mathrm{Ni}(\mathrm{II}) ; \mathrm{Zn}(\mathrm{II})$ and $\mathrm{Cd}(\mathrm{II})$ on biogasification of potato waste. J Environ Biol 27:61-66

Kuntze K, Kiefer P, Baumann S, Seifert J, von Bergen M, Vorholt JA, Boll M (2011) Enzymes involved in the anaerobic degradation of meta-substituted halobenzoates. Mol Microbiol 82:758-769
Kuo CW, Genthner BRS (1996) Effect of added heavy metal ions on biotransformation and biodegradation of 2-chlorophenol and 3 -chlorobenzoate in anaerobic bacterial consortia. Appl Environ Microbiol 62:2317-2323

Lang XM, Shi XC, Wang GG (2007) New micro-electrolytic and bioenhancing processing technology in treating nitrobenzene sewage. J Saf Environ 7:66

Leighton IR, Forster CF (1998) The effect of heavy metals on a thermophilic methanogenic upflow sludge blanket reactor. Bioresour Technol 63:131-137

Li C, Fang HHP (2007) Inhibition of heavy metals on fermentative hydrogen production by granular sludge. Chemosphere 67:668-673

Liew LN, Shi J, Li Y (2011) Enhancing the solid-state anaerobic digestion of fallen leaves through simultaneous alkaline treatment. Bioresour Technol 102:8828-8834

Lin CY (1992) Effect of heavy metals on volatile fatty acid degradation in anaerobic digestion. Wat Res 26:177-183

Lin CY (1993) Effect of heavy metals on acidogenesis in anaerobic digestion. Wat Res 27:147-152

Lin CY, Chen CC (1999) Effect of heavy metals on the methanogenic UASB granule. Wat Res 33:409-416

Lin CY, Shei SH (2008) Heavy metal effects on fermentative hydrogen production using natural mixed microflora. Int $\mathrm{J}$ Hydrogen Energy 33:587-593

Lin CY, Chou J, Lee YS (1998) Heavy metal-affected degradation of butyric acid in anaerobic digestion. Bioresour Technol 65:159-161

Lins P, Reitschuler C, Illmer P (2012) Development and evaluation of inocula combating high acetate concentrations during the start-up of an anaerobic digestion. Bioresour Technol 110: $167-173$

Liu DW, Liu DP, Zeng RJ, Angelidaki I (2006) Hydrogen and methane production from household solid waste in the two-stage fermentation process. Wat Res 40:2230-2236

Lo HM, Chiang CF, Tsao HC, Pai TY, Liu MH, Kurniawan TA, Chao $\mathrm{KP}$, Liou CT, Lin KC, Chang CY, Wang SC, Banks CJ, Lin CY, Liu WF, Chen PH, Chen CK, Chiu HY, Wu HY, Chao TW, Chen YR, Liou DW, Lo FC (2012) Effects of spiked metals on the MSW anaerobic digestion. Waste Manag Res 30:32-48

Lovley DR, Nevin KP (2011) A shift in the current: new applications and concepts for microbe-electrode electron exchange. Curr Opin Biotechnol 22:441-448

Ludden PW, Robert GP (1995) The biochemistry and genetics of nitrogen fixation by photosynthetic bacteria. In: Blankenship BE, Madigan MT, Bauer CE (eds) Anoxygenic photosynthetic bacteria. Kluwer Academic Publishers, Dordrecht, pp 929-947

Luostarinen S, Rintala J (2007) Anaerobic on-site treatment of kitchen waste in combination with black water in UASB-septic tanks at low temperatures. Bioresour Technol 98:1734-1740

Massé D, Gilbert Y, Topp E (2011) Pathogen removal in farm-scale psychrophilic anaerobic digesters processing swine manure. Bioresour Technol 102:641-646

Mata-Alvarez J, Macé S, Llabrés P (2000) Anaerobic digestion of organic solid wastes. An overview of research achievements and perspectives. Bioresour Technol 74:3-16

Mishra SR, Bharati K, Sethunathan N, Adhya TK (1999) Effects of heavy metals on methane production in tropical rice soils. Ecotoxicolo Environ Saf 44:129-136

Nadais H, Capela I, Arroja L, Duarte A (2005) Treatment of dairy wastewater in UASB reactors inoculated with flocculent biomass. Wat SA 31:603-608

Nyholm JR, Lundberg C, Andersson PL (2010) Biodegradation kinetics of selected brominated flame retardants in aerobic and anaerobic soil. Environ Pollut 158:2235-2240 
Oleszkiewicz JA, Sharma VK (1990) Stimulation and inhibition of anaerobic processes by heavy metals: a review. Biol Wastes 31:45-67

Parawira W, Murto M, Read JS, Mattiasson B (2004) Volatile fatty acid production during anaerobic digestion of solid potato waste. J Chem Technol Biotechnol 79:673-677

Pardue JH, Kongara S, Jones WJ (1996) Effect of cadmium on reductive dechlorination of trichloroaniline. Environ Toxicol Chem 15:1083-1088

Patel VB, Patel AR, Patel MC, Madamwar DB (1993) Effect of metals on anaerobic digestion of water hyacinth-cattle dung. Appl Biochem Biotechnol 43:45-50

Pattra S, Sangyoka S, Boonmee M, Reungsang A (2008) Biohydrogen production from the fermentation of sugarcane bagasse hydrolysate by Clostridium butyricum. Int J Hydrogen Energy 33:5256-5265

Peng K, Li X, Luo C, Shen Z (2006) Vegetation composition and heavy metal uptake by wild plants at three contaminated sites in Xiangxi area; China. J Environ Sci Health Part A 40:65-76

Pind PF, Angelidaki I, Ahring BK (2003) Dynamics of the anaerobic process: effects of volatile fatty acids. Biotechnol Bioeng 82:791801

Raposo F, Banks CJ, Siegert I, Heaven S, Borja R (2006) Influence of inoculum to substrate ratio on the biochemical methane potential of maize in batch tests. Process Biochem 41:1444-1450

Roberts DJ, Venkataraman N, Pendharkar S (1998) The effect of metals on biological remediation of munitions contaminated soil. Environ Eng Sci 15:265-277

Sanchez E, Borja R, Weiland P, Travieso L, Martin A (2000) Effect of temperature and $\mathrm{pH}$ on the kinetics of methane production, organic nitrogen and phosphorus removal in the batch anaerobic digestion process of cattle manure. Bioprocess Biosys Eng $22: 247-252$

Sanchez E, Borja R, Travieso L, Martin A, Colmenarejo MF (2005) Effect of organic loading rate on the stability, operational parameters and performance of a secondary upflow anaerobic sludge bed reactor treating piggery waste. Bioresour Technol 96:335-344

Sandrin TR, Maier RM (2003) Impact of metals on the biodegradation of organic pollutants. Environ Health Perspect 111:1093-1101

Schmidt JE, Ahring BK (1996) Granular sludge formation in upflow anaerobic sludge blanket UASB) reactors. Biotechnol Bioeng 49:229-246

Şengör SS, Barua S, Gikas P, Ginn TR, Peyton B, Sani RK, Spycher NF (2009) Influence of heavy metals on microbial growth kinetics including lag time: mathematical modeling and experimental verification. Environ Toxicol Chem 28:2020-2029

Siegert I, Banks C (2005) The effects of volatile fatty acid additions on the anaerobic digestion of cellulose and glucose in batch reactors. Process Biochem 40:3412-3418

Sondhi A, Guha S, Harendranath CS, Singh A (2010) Effect of aluminum $\left(\mathrm{Al}^{3+}\right)$ on granulation in upflow anaerobic sludge blanket reactor treating low-strength synthetic wastewater. Wat Environ Res 82:715-724

Song YC, Kwon SJ, Woo JH (2004) Mesophilic and thermophilic temperature co-phase anaerobic digestion compared with singlestage mesophilic- and thermophilic digestion of sewage sludge. Wat Res 38:1653-1662

Tiwari MK, Guha S, Harendranath CS, Tripathi S (2006) Influence of extrinsic factors on granulation in UASB reactor. Appl Microbiol Biotechnol 71:145-154

Torkian A, Eqbali A, Hashemian SJ (2003) The effect of organic loading rate on the performance of UASB reactor treating slaughterhouse effluent. Resour Conserv Recycl 40:1-11
Uemura S, Harada H (1995) Inorganic composition and microbial characteristics of methanogenic granular sludge grown in a thermophilic upflow anaerobic sludge blanket reactor. Appl Microbiol Biotechnol 43:358-364

Veeken A, Kalyuzhnyi S, Scharff H, Hamelers B (2000) Effect of pH and VFA on hydrolysis of organic solid waste. J Environ EngASCE 126:1076-1081

Velmurugan B, Ramanujam RA (2011) Anaerobic digestion of vegetable wastes for biogas production in a fed-batch reactor. Int J Emerging Sci 1:478-486

Vlyssides A, Barampouti EM, Mai S (2009) Influence of ferrous iron on the granularity of a UASB reactor. Chem Eng J 146:49-56. http://dx.doi.org/10.1016/j.cej.2008.05.011

Wang J, Wan W (2008) Influence of $\mathrm{Ni}^{2+}$ concentration on biohydrogen production. Bioresour Technol 99:8864-8868

Wang Y, Zhang Y, Wang J, Meng L (2009a) Effects of volatile fatty acids concentrations on methane yield and methanogenic bacteria. Biomass Bioenergy 33:848-853

Wang Y, Wu C, Wang X, Zhou S (2009b) The role of humic substances in the anaerobic reductive dechlorination of 2,4dichlorophenoxyacetic acid by Comamonas koreensis strain CY01. J Hazard Mater 164:941-947

Wani PA, Khan MS, Zaidi A (2012) Toxic effects of heavy metals on germination and physiological processes of plants. Toxic Heavy Met Legum Bioremediation 2:45-66

Weaver PF, Lien S, Seibert M (1980) Photobiological production of hydrogen. Sol Energy 24:3-45

Weiland P (2010) Biogas production: current state and perspectives. Appl Microbiol Biotechnol 85:849-860

Xue W, Wu C, Xiao K, Huang X, Zhou H, Tsuno H, Tanaka H (2010) Elimination and fate of selected micro-organic pollutants in a full-scale anaerobic/anoxic/aerobic process combined with membrane bioreactor for municipal wastewater reclamation. Wat Res 44:5999-6010

Yin F, Zhang WD, Liu SQ, Li JC, Xu R, Chen XB (2011) Discussing on biochemical pathway of anaerobic fermentation for hydrogen and methane production by Eupatorium Adenophorum Spreng based on biochemical materials. In: Zhang $\mathrm{H}$, Jin D (eds) Advanced Research on Material Science, Environmental Science and Computer Science. Trans Tech Publications, Switzerland, pp 398-403

Yoneyama Y, Nishii A, Nishimoto M, Yamada N, Suzuki T (2006) Upflow anaerobic sludge blanket (UASB) treatment of supernatant of cow manure by thermal pre-treatment. Wat Sci Technol $54: 221-227$

Yu HQ, Fang HHP (2001) Inhibition by chromium and cadmium of anaerobic acidogenesis. Wat Sci Technol 43:267-274

Yu HQ, Mu Y (2006) Biological hydrogen production in a UASB reactor with granules. II: reactor performance in 3-year operation. Biotechnol Bioeng 94:988-995

Yu HQ, Fang HHP, Tay JH (2000) Effects of $\mathrm{Fe}^{2+}$ on sludge granulation in upflow anaerobic sludge blanket reactors. Wat Sci Technol 41:199-205

Yue ZB; Yu HQ; Wang ZL (2007) Anaerobic digestion of cattail with rumen culture in the presence of heavy metals. Bioresour Technol 98:781-786. http://dx.doi.org/10.1016/j.biortech.2006. 03.017

Zayed G, Winter J (2000) Inhibition of methane production from whey by heavy metals-protective effect of sulfide. Appl Microbiol Biotechnol 53:726-731

Zhang YS; Zhang ZY; Suzuki K; Maekawa T (2003) Uptake and mass balance of trace metals for methane producing bacteria. Biomass Bioenergy 25:427-433. http://dx.doi.org/10.1016/ S0961-9534(03)00012-6 
Zhang G-L, Yang F-G, Zhao Y-G, Zhao W-J, Yang J-L, Gong Z-T (2005) Historical change of heavy metals in urban soils of Nanjing; China during the past 20 centuries. Environ Int 31:913-919
Zhu H, Fang HHP, Zhang T, Beaudette LA (2007) Effect of ferrous ion on photo heterotrophic hydrogen production by Rhodobacter sphaeroides. Int J Hydrogen Energy 32:4112-4118. http://dx.doi. org/10.1016/j.ijhydene.2007.06.010 